\title{
Economic Analysis Relationship in Determining The Size of Parliamentary Threshold in Indonesia
}

\author{
Sholahuddin Al-Fatih \\ Faculty of Law, University of Muhammadiyah Malang, \\ Jl. Bandung 1 Malang, Jawa Timur \\ * Correspondence email: sholahuddin.alfath@gmail.com
}

\begin{abstract}
This research tries to discuss the relationship of economic factors in the establishment of a legal norm. Through conceptual and statutory approaches, this study tries to examine the concept of the relationship between economics and the law initiated by Richard A. Posner. This research makes the establishment of the norm on the size of the parliamentary threshold in the implementation of legislative elections as a benchmark for the relationship between the economy and the law. The results of this study show that changes in the size of the parliamentary threshold can be understood as an open legal policy agreed upon by lawmakers. The existence of rules on open legal policy makes economic and legal relations in determining the norms of parliamentary threshold size become real. This research is expected to help academics and legal practitioners to dig deeper into the relationship between economics and law, so as to understand the advantages and disadvantages that may result from such relationships.
\end{abstract}

KEYWORDS: Law; Economy, Parliamentary Threshold

\section{INTRODUCTION}

Indonesia has implemented a parliamentary threshold since the reforms were implemented and Indonesia hasadopteda new round of reforms, including in the renewal of the state system. In the beginning, the parliamentary threshold was known as the electoral threshold (Fatih, 2018). The electoral threshold is applied to limit the number of electoral parties in the next election period (Mietzner, 2020). At the time of the initial enactment, the electoral threshold was about $2.5 \%$. At the time, there were some parties that failed to meet the electoral threshold, such as Partai Keadilan (the Justice Party). As a condition of being able to participate in the next election, the Justice Party must change its name and eventually change to the Prosperous Justice Party or Partai Keadilan Sejahtera (PKS) that survives to this day. Not only the name, the party that failed to pass the electoral threshold is also required to change the logo or image of the party.

The electoral threshold is considered a discriminatory policy. Thus, many argue that the policy is reviewed (Effendi, 2017). After the electoral threshold passed, a new policy was born called the parliamentary threshold (Al-Fatih, 2019). The parliamentary threshold is used as the new norm to limit the number of political parties that pass into parliament. If the previous electoral threshold was used to limit the number of parties that would follow the election instead, it would not be the parliamentary threshold. Thus, the 
application of the parliamentary threshold is considered more logical and does not violate the constitutional rights of citizens.

Historically, the size of the parliamentary threshold has always risen since it was first implemented in 2009 (Adelina, 2018). In the 2009 election, the government implemented the concept of a parliamentary threshold of $2.5 \%$ and this concept was considered quite effective, because the number of parties that qualified for parliament was not very much compared to the number of political parties of the election participants. At the 2014 election, the government implemented the concept of a parliamentary threshold of $3.5 \%$, or up $1 \%$ compared to the previous election period, but was considered less effective. Meanwhile, in the 2019 elections, the government implemented the concept of a parliamentary threshold of $4 \%$. Some parties failed to qualify for parliament, such as Perindo, PSI, PKPI, PBB and so on.

On the parliamentary threshold and the size of which has changed, some political parties have expressed their aspirations. Quoted from research conducted by Muhammad Alghaffar, there was a different response from political parties regarding the implementation of the parliamentary threshold in the 2019 elections (Alghaffar, 2020). Nasdem's party responded with this application as a challenge in order to improve the quality of democracy. The PKS responded to this application to reduce the compound of party ideology in Indonesia. PDI Perjuangan responds with the application of this faction of political parties in the House of Representatives can fill all positions in the Legislature so that the role of the political party can run to the maximum.

The mixed response from the political parties, in fact, indicates there is something that cannot be conveyed from the application of the parliamentary threshold itself. Whether it's because of the bias of the parliamentary threshold or the determination of the size of the old parliamentary threshold seems to be just a political deal with no basis in which the theory governs it (Firdaus, 2011). In the naked eye, the larger the parliamentary threshold is set, the more favorable it will be for the major parties. Because, mathematically, the votes of smaller parties that do not qualify in the parliamentary threshold count will be the remaining votes contested by the party that has passed the parliamentary threshold. It is this factor that reinforces the hypothesis that the parliamentary threshold was created not only to simplify the number of political parties in parliament, but there are other elements that must be scientifically proven. In proportional electoral system, there were 3 formulas to decide parliamentary threshold scientifically, namely: 1) Quota Method (Tupper $=1 / 2 \mathrm{~m}$ or Tupper $=100 \%:(1+\mathrm{m})$ or Tlower $=1 /(\mathrm{m}+1)$ or Tlower $=100 \%: 2 \mathrm{~m}) ; 2)$ Divisor Method $($ Teff $=75 \% /(\mathrm{m}+1))$; or 3) Taagepera Formulas $(\mathrm{T}=75 \% /((\mathrm{M}+1) * \sqrt{\mathrm{E}})$ or $\mathrm{T}=75 \% /((\mathrm{S} / \mathrm{E})+1) * \sqrt{\mathrm{E}})$ or $\mathrm{T}=$ $\left.75 \% /\left((\mathrm{S} / \mathrm{E}) / \mathrm{E}^{*} \sqrt{\mathrm{E}}\right)\right)$ (Al-fatih, Safaat, \& Dahlan, 2014) (Fatih, 2018).

Through this research, the authors hope to find a relationship between the determination of the parliamentary threshold and factors outside the law, such as economic factors in scope of profit and loss, especially in making public policies. Richard A. Posner was one of the people who initiated the relationship between economics and the law. Pointing to Posner's ideas and thinking, this research raises the topic of economic factors in determining the size of the parliamentary threshold in Indonesia. This research is expected to contribute in the field of electoral law in order to realize democratic elections and produce the representatives of the people who are trusting and responsible. 


\section{RESEARCH METHODS}

This research is a type of legal research with conceptual approach and statutory approach (Peter Mahmud Marzuki, 2014). Legal research is a study that examines norms, relating to overlap, emptiness and blurring of existing norms. The norm that is being reviewed in this study is related to the norm of the size of the parliamentary threshold. The concept used as a measuring instrument is the concept of willingness between economics and law, while the legislation used in this study is the Law on Elections. Through prescriptive analysis (Peter Mahmud Marzuki, 2017), the authors try to find new arguments related to the relationship between economic analysis and the law in determining the size of parliamentary thresholds in Indonesia.

\section{RESULT AND DISCUSSION}

\section{The Relationship between Economic Analysis and Law}

The relationship between economic factors and the law is not new. this idea originated from the teachings of legal theory developed by Jeremy Bentham and his utilitarians. That the law must bring benefits, then the most logical and measurable benefits can certainly be seen from economic factors. Jeremy Bentham's idea inspired Gary Becker (Andreas \& Laracaka, 2019) to Richard A. Posner (Posner, 1985). Posner also believes that law enforcement and lawmakers implicitly use economic analysis as one of the foundations for establishing norms and enforcing law enforcement (Posner, 1985).

In general, the analysis of the connectedness between the economy and the law, pointing to the idea that any normal person up to a certain point will certainly do a profit or loss calculation that could affect his actions (Andreas \& Laracaka, 2019). The calculation of profit or loss that understands the behavior of the person, sometimes subjective (Eide, Erling. Paul H. Rubin, 2006). So, it can also be said that the relationship between economics and law is not an objective relationship, but more towards subjectively looking at situations and conditions.

In order not to get caught up in that subjective definition, it is good to look at the definition of the relationship between economics and the law presented by some experts. Cento Veljanovski mentioned that economic analysis of the law can be interpreted as the use of economic theory, especially regarding price theory and statistical methods to test the formation, process and results of law and legal institutions (Veijanovski, 1990). Veljanovski's view is rational and based on legal logic, a little bit certainly acceptable, because in many cases, economic analysis is indeed used as a knife to examine and solve existing legal problems.

In another view, Jules L. Colemen mentions that economic analysis is a tool for explaining legal products and court rulings (Coleman, 1980). While Robert Cooter and Thomas Ulen saw that economic and legal analysis were two different disciplines, when put together it could have a tremendous impact on both (Cooter, 2000). Economic analysis can be very beneficial for advocates or anyone interested in understanding public policy. Because majority public policy is measured quantitatively through economics.

From some of the above views, it can be concluded that economics and law are two different disciplines. However, this does not mean that the two can be used as study 
materials at the same time, but the relationship between the two can actually make the results and solution of a problem more measurable and feel the benefit. Economic analysis can serve as a basis for explaining a judge's ruling, assessing a public policy, including in making a legal product.

\section{Determination of Parliamentary Threshold based on Economic Analysis}

Richard Posner in the development of his way of thinking, has gone through a phase of shifting from studying law and economics to studying economic analysis of law (Harnay \& Marciano, 2009). Posner sees that economic analysis can be used as a method to analyze legal issues that could impact a judge's ruling. Posner's explanation is quite rational, given that Posner is large and developed in a common law country that bases its laws on court/judge rulings. Becoming interesting to discuss is whether posner's idea can also be applied in civil law country or not.

Posner's idea later became a hot topic of discussion by legal activists, one of whom was discussed by Ch. Himawan (Himawan, 1991). Himawan argues that one way to resurrect the rule of law in Indonesia is to water down economic concepts to the laws of Indonesia that are asleep. Because, by legal experts who assess the law pranata as a commodity, they will always keep the commodity quality with construction and renewal. In this way, Indonesian law can be a good law, not only in the ASEAN region but also Asia and the world.

Himawan in presenting the idea of economic analysis of the law, taking two concepts as measuring instruments, namely maximization and balance (Himawan, 1991). In the concept of maximization, the law pranata is used as a tool to achieve the maximum target for solving existing problems. While in the concept of balance, try to control the maximum effort against the existing legal pranata. Both concepts can be used as a concept to measure the topic to be discussed, namely the determination of the size of the parliamentary threshold in legislative elections in Indonesia.

As it is known, the parliamentary threshold has increased in size since it was first implemented. The parliamentary threshold has risen from $2.5 \%$ to $4 \%$ at the last election in 2019 (Ginting \& Saragih, 2018). This is certainly a phenomenon of the government's efforts to maximise the size of the existing parliamentary threshold. Because, history has noted, some countries instead hit a much larger parliamentary threshold than Indonesia. Countries such as Turkey (Mouliza K.D Sweinstani, 2019) and some other European countries, apply the parliamentary threshold on unnatural borders up to $10 \%$ (Baskan, 2012). Thus, if looking at the concept of maximization, then the government has not been too bold to maximize the size of the parliamentary threshold.

The government seems to be looking at the concept of balance. Where, the government is trying to take the middle ground about the size of the parliamentary threshold. The middle ground taken by the government appears to be at the last parliamentary threshold, which is $4 \%$. A $4 \%$ indicated that the government was trying to balance and spread the vote among the political parties of the election participants. Perhaps, the government has also not been too bold to take the risk of being referred to as the voice of the people. Because, so far, the votes of political parties that fail to meet the parliamentary threshold become the remaining votes whose seats are converted to political parties that pass the parliamentary threshold. 
Nevertheless, the government should not only look at one model of analysis in making a policy. There are several other factors that also need to be considered, such as human rights instruments (Adelina, 2018). This is important to consider because the application of the parliamentary threshold is often considered to castrate one's political rights. Thus, it is also necessary to apply this parliamentary threhsold to accommodate the political rights of the people (Tata Strata, Hufron, 2019). If so, then logically, the size of the parliamentary threshold in Indonesia needs to be lowered. Because, the smaller the parliamentary threshold, the greater the chance for political parties to qualify for parliament. Thus, political rights and the right to vote and elected citizens will be protected.

Therefore, the use of economic analysis in determining the size of the parliamentary threshold is considered inappropriate. The efficiency and concept of profit-loss contained in the economic analysis as conveyed by Richard A. Posner, will be to suggest that the pranata parliamentary threshold as a commodity (Rismawati, 2015). This is prone to causing transactional effects. The condition is certainly quite dangerous in state practice. Thus, it would be ideal if the determination of the parliamentary threshold not only looked at the disadvantages, but also looked at aspects of human rights, social justice and people's sovereignty.

\section{CONLCUSION}

In closing, based on the above descriptions and discussions, it can be concluded that in the preparation of parliamentary threhsold, the government has used economic analysis in accordance with the concept of maximization and balance. Nevertheless, there has not been any benefit in the use of economic analysis in the preparation of parliamentary threhsold, because the goal of realizing a simple multi-party system has not been achieved. These shortcomings are important records and findings in the dynamics of Indonesia's strict ness. The government not only uses economic analysis in the preparation of parliamentary threhsold, but also looks at aspects of Human Rights and people's sovereignty. Because the application of parliamentary threshold in elections is not only about profit loss, but also the fulfillment and guarantee of rights for all Indonesian citizens.

\section{REFERENCES}

Adelina, A. (2018). RELEVANSI AMBANG BATAS PARLEMEN (PARLIAMENTARY THRESHOLD) DENGAN SISTEM PRESIDENSIAL DI INDONESIA (Universitas Islam Indonesia). Retrieved from https://dspace.uii.ac.id/handle/123456789/5874

Al-Fatih, S. (2019). Akibat Hukum Regulasi tentang Threshold dalamPemilihan Umum Legislatif dan Pemilihan Presiden: Kajian Putusan Mahkamah Konstitusi Nomor 52/PUU-X/2012 dan Nomor 14/PUU-XI/2013. Jurnal Yudisial, 12(1), 17-38. https://doi.org/10.29123/jy.v12i1.258

Al-fatih, S., Safaat, M. A., \& Dahlan, M. (2014). Reformulasi Parliamentary Threshold Yang Berkeadilan Dalam Pemilu Legislatif Di Indonesia. Jurnal Hukum, 20. Retrieved from http://hukum.studentjournal.ub.ac.id/index.php/hukum/article/view/1018/10 07

Alghaffar, M. (2020). ANALISIS YURIDIS KOMPARATIF PARLIAMENTARY THRESHOLD DALAM UNDANGUNDANG NOMOR 7 TAHUN 2017 TENTANG PEMILIHAN UMUM 
DENGAN UNDANG-UNDANG TERKAIT DI ERA REFORMASI (Universitas Negeri Semarang). Retrieved from https://lib.unnes.ac.id/38249/

Andreas, M. N., \& Laracaka, R. (2019). Analisa Ekonomi terhadap Hukum dalam Pemidanaan Partai Politik melalui Pertanggungjawaban Korporasi dalam Perkara Tipikor. Jurnal Antikorupsi, 5(1), 127-167.

Baskan, F. \& A. G. (2012). Turkey's June 2011 Parliamentary Elections. Journal of Balkan and Near Eastern Studies, 14(1), 165-174. https://doi.org/https://doi.org/10.1080/19448953.2012.656983

Coleman, J. L. (1980). Efficiency, Exchange, and Auction: Philosophical Aspects of the Eco nomic Approach to Law. California Review, 88.

Cooter, R. T. U. (2000). Law and Economics (3rd ed.). Addison Wisiey Longman Inc.

Effendi, A. (2017). Studi Komparatif Pengaturan Sistem Pemilihan Umum Anggota Dewan Perwakilan Rakyat Di Indonesia. Fiat Justisia, 10(2), 295-316. https://doi.org/10.25041/fiatjustisia.v10no2.746

Eide, Erling. Paul H. Rubin, J. M. S. (2006). Economics of Crime: Foundations and Trends in Microeconomics. Massachusets: Now Publisher.

Fatih, S. Al. (2018). Implementasi Parliamentary Threshold Dalam Pemilihan Anggota Dprd Provinsi Dan Dprd Kabupaten/Kota. Ahkam: Jurnal Hukum Islam, 6(2). https://doi.org/10.21274/ahkam.2018.6.2.363-388

Firdaus, S. (2011). Relevansi Parliamentary Threshold Terhadap Pelaksanaan Pemilu Yang Demokratis. Jurnal Konstitusi, 8(2), 91-112.

Ginting, F. P. P., \& Saragih, A. (2018). Ilusi Demokrasi Substansial di Indonesia: Sebuah Kritik Terhadap Implementasi Parliamentary Treshlod. Politeia: Jurnal Ilmu Politik, 10(2), 79-90. https://doi.org/10.32734/politeia.v10i2.630

Harnay, S., \& Marciano, A. (2009). Posner, economics and the law: From "law and economics" to an economic analysis of law. Journal of the History of Economic Thought, 31(2), 215-232. https://doi.org/10.1017/S1053837209090208

Himawan, C. (1991). Pendekatan Ekonomi terhadap Hukum sebagai Sarana Pengembalian Wibawa Hukum. Hukum Dan Pembangunan, 21(5), 421-445.

Mietzner, M. (2020). Authoritarian innovations in Indonesia: electoral narrowing, identity politics and executive illiberalism. Democratization, 27(6), 1021-1036. https://doi.org/https://doi.org/10.1080/13510347.2019.1704266

Mouliza K.D Sweinstani. (2019). Formula Konversi Suara Saint Lague dan Dampaknya pada Sistem Kepartaian: Evaluasi Pemilu Serentak 2019. Jurnal Penelitian Politik (LIPI), 16(2), 111-124. Retrieved from http://ejournal.politik.lipi.go.id/index.php/jpp/article/view/812/549

Peter Mahmud Marzuki. (2014). Penelitian Hukum. Jakarta: Kencana Prenada Media Group.

Peter Mahmud Marzuki. (2017). Penelitian Hukum: Edisi Revisi (Cetakan ke). Retrieved from https://books.google.co.id/books?id=CKZADwAAQBAJ\&printsec=frontcover\&dq =Marzuki,+Peter+Mahmud,+(2014),+Penelitian+Hukum,+Cetakan+ke9,+Jakarta:+Kencana+Media+Group.\&hl=id\&sa=X\&ved=0ahUKEwiNlIjqlbTpAhX WWisKHWktCXAQ6AEIMjAB\#v=onepage\&q\&f=false

Posner, R. (1985). An Economic Theory of The Criminal Law. Columbia Law Review, $85(6)$.

Rismawati, S. D. (2015). Menebarkan Keadilan Sosial dengan Hukum Progresif di Era Komodifikasi Hukum. Jurnal Hukum Islam, 13(1), 1-12. 
Tata Strata, Hufron, S. S. (2019). AMBANG BATAS PARLEMEN (PERLIAMENTARY THRESHOLD) DAN ASAS DEMOKRASI. Jurnal Akrab Juara, 4(5), 229-245. Retrieved from http://akrabjuara.com/index.php/akrabjuara/article/view/880/781

Veijanovski, C. (1990). The Economics of Law: An introductory Text. The Institute of Economic Affairs.

\section{ACKNOWLEDGEMENT}

The author would like thank to Prof. Moh. Fadli and Prof. Achmad Sodiki who giving knowledge and advice in Philosophy of Law course in Doctoral of Law, Brawijaya University. This research was one of the topics in those courses. 